\title{
Coopetition Strategy: A Research on Traditional Airlines
}

\section{Ortaklaşa Rekabet Stratejisi: Geleneksel Havayolu Şirketleri Üzerine Bir Araştırma}

\author{
Gökhan TANRIVERDİ* \\ Ayşe KÜÇÜKYILMAZ**
}

\begin{abstract}
Employed by two or more competitor companies particularly in highly competitive markets, the coopetition strategy is a business strategy where competition goes hand in hand with cooperation. Airline companies employ coopetition strategy to overcome such unfavorable conditions and to achieve sustainable competitive advantages. For that purpose, they make agreements with competitor airline companies within or apart from the strategic alliances. The purpose of this study is to identify the experiences of the airline companies practicing coopetition strategies. To that end, semi-structured interviews have been carried out with senior managers of five traditional airlines. The primary result of the study is that the coopetition strategy is indispensable for the sustainability of the airline business. Another remarkable result is that competition boards are required to lead up practices which will benefit airline companies.
\end{abstract}

Key Words: Coopetition, Cooperation with Competitor, Airline Business, Strategic Airline Alliances, Sustainability, Traditional Airlines.

Öz

Ortaklaşa rekabet stratejisi, iki ya da daha fazla rakip işletme tarafından özellikle rekabet yoğun pazarlarda kullanılan, rekabet ve işbirliğinin aynı anda gerçekleştirildiği bir işletme stratejisidir. Havayolu şirketleri, kendileri için istemedikleri bazı olumsuzlukların üstesinden gelmek ve sürdürülebilir rekabet avantajı kazanmak için ortaklaşa rekabet stratejisini kullanmaktadır. Bu doğrultuda, rakip havayolu şirketleri ile stratejik havayolu ittifakları dahilinde ve haricinde anlaşmalar yapılmaktadır. Bu araştırmanın amacı, ortaklaşa rekabet stratejisini uygulayan havayolu şirketlerinin deneyimlerinin ortaya konmasıdır. Bu amaçla, beş geleneksel havayolu şirketinin üst düzey yöneticisi ile yarı yapılandırılmış görüşme yapılmıştır. Araştırmada ortaya çıkan temel sonuç, ortaklaşa rekabet stratejisinin havayolu sektörünün sürdürülebilirliği için olmazsa olmaz olduğudur. Bir diğer kayda değer sonuç ise rekabet kurullarının havayolu şirketlerine fayda sağlayacak uygulamaların önünü açması gerektiğidir.

Anahtar Kelimeler: Ortaklaşa Rekabet, Rakiple İşbirliği, Havayolu Sektörü, Stratejik Havayolu İttifakları, Sürdürülebilirlik, Geleneksel Havayolları.

\section{Introduction}

Until the 1990s, when globalization started to accelerate, competition and cooperation were used to be considered as two separate strategies in the business world. Until then, especially the companies in severely competitive industries used to consider each other as opposite parties in war. Gore Vidal suggests that in this approach it is not sufficient for companies to be successful; other companies should fail too. However, companies do not possess all the capabilities and resources necessary to compete in conditions of fierce competition in most time. Furthermore, no company seems to be willing to assume alone all the risks to struggle against strong competitors. In these new conditions, companies need new strategies to cope with certain internal and external problems. At this point, companies either prefer a cooperation strategy or employ simultaneously both competition and cooperation strategies to benefit from the advantages of both strategies (see Brandenburger and Nalebuff, 1998, p. 19-20; Akdoğan and Cingöz, 2012, p. 252; Yami et al., 2010, p. 2).

Towards the end of the 20th century, where competition started to intensify, it was Ray Noorda, founder of Novell, a network software company, who first used the concept "coopetition" (Ganguli, 2007, p. 6). Coopetition is a relationship with a nature of mixed-

\footnotetext{
* Arş. Gör., Erzincan Üniversitesi Sivil Havacilik MYO Havacilik Yönetimi, gkhantanriverdi@gmail.com.

** Doç. Dr. Anadolu Üniverssitesi Havacılık ve Uzay Bilimleri Fakültesi Havacılık Yönetimi Bölümü, akucukyilmaz@gmail.com.
}

Tanrıverdi, G., Küçükyılmaz, A., (2018). Coopetition Strategy: A Research on Traditional Airlines, Gaziantep University Journal of Social Sciences, 17 (1), 317-333, DOI: 10.21547/jss.333589, Submission Date: 08-08-2017, Acceptance Date: 04-10-2017.

Araştırma Makalesi. 
motives where parties involved in the relationship can create value by complementing each other's activity (Bonel and Rocco, 2007, p. 71). What lies at the bottom of coopetition, which is employed as a business strategy, is that two or more competitor companies develop cooperation in certain areas while at the same time maintaining competition in others. These collaborations are carried out with the aim of providing mutual benefits. (Luo, 2007; Tsai, 2002) An analogy is used also in the literature for this strategy like "sleeping with the enemy" in terms of doing business with the competitor (Quint, 1997, p. 7).

Bringing their resources together with their competitors, companies may derive competitive advantages over other actors in the market. (Bengtsson and Kock, 2000, p. 424). This strategy provides the competitors coming together with the benefits of value added, safe communication, increased efficiency and quality, access to raw materials and limited resources, and shared and reduced risks. In addition to co-utilization of resources and complementary advantages in a synergy, the strategy provides further advantages to the partners of coopetition than other market actors especially with respect to access to limited resources (Czakon et al., 2014, p. 129).

Coopetition, which becomes more crucial each day passing, has been largely employed in many industries lately (Sroka, 2013). The airline industry is by no doubt one of those industries. Due to its characteristics, the activities in the airline industry bring about high costs, and the structure of the industry is strongly vulnerable to uncertainties, risks and crises. In order to be able to cope with high costs, uncertainties and risks and to derive operational benefits, airline companies employ coopetition strategies.

The purpose of this qualitative research is to identify the experiences of airline companies practicing coopetition strategies. In this respect, the study is based on qualitative research and face-to-face interviews with senior managers of the airline companies practicing coopetition strategy are made to have their detailed views on the strategy. The research questions of the study are as follows:

- What are the practices of the airline companies employing coopetition strategy?

- What are the considerations of the airline companies employing a coopetition strategy on the coopetition strategy?

- What do the airline companies believe that the coopetition strategy looks like?

\section{Literature Review}

Coopetition has been one of the most researched topic in business literature in recent times. In most industries, there have been many studies on different topics carried out on coopetition strategy to address different aspects of the strategy. Some of these studies based on nature of coopetition, coopetitive relations between businesses (horizontal or vertical), competitor selection process, organizational learning, customer-supplier relations, knowledge sharing, innovation and also resource based theory (Akdoğan et al., 2015; Meneses, 2015; Solesvik and Westhead, 2010; Kim et al., 2013; Lacoste, 2014; Nasr et al., 2015; Stein and Ginevicius, 2010; Wilhelm, 2011; Akdoğan and Cingöz, 2012; Gnyawali and Park, 2009; Huang and Chu, 2015; Morris et al., 2007; Thomason et al., 2013; Demirel et al., 2011; Demirel et al., 2013; Sroka, 2013). However, in the airline industry, limited studies have been carried out in the sense of coopetition.

Current studies relating coopetition in the airline industry usually aim at revealing the structure of coopetition and showing how coopetition is practiced. Klimas (2014) studies the coopetition structure in the airline supply chain. In this respect, he analyzed cooperation and 
competition in different levels, scopes and areas, and identified four different forms of coopetition: national coopetition, global coopetition, mixed coopetition, and all-purpose coopetition. Kozyra (2012) argues coopetition is an extensive concept and strategic alliances are a specific form of coopetition. Zhang and Frazier (2011) also points out that strategic alliances are form of coopetition. In line with, Chang and Chiu (2016) discusses whether members of strategic airline alliances make coopetition or not and the study reveals that competitors whose resources are similar high with low market commonality may cooperate via resource allocation. Chiambaretto and Fernandez (2016) researches coopetition and alliance portfolio through the example of Air France to explore the formation of the Alliance portfolio and its development over time. Chen and Hao (2013) explores to what extend strategic airline alliance benefits to member airlines.

We also examined researches on strategic airline alliances in scope of coopetition by looking Klimas (2014) and Kozyra (2012). There are superabundant researches dealing with strategic airline alliances in different ways in the literature. Rhoades and Lush (1997) reviews the strategic airline alliances and suggests a new alliance typology in two significant aspects: the degree to which resources are committed and the complexity of the arrangement. Using the typology, the writers offer a series of propositions on the stability and duration of different types of alliances. Zhang et al. (2004) develops an oligopoly model to measure the impact of an airline cargo alliance on competition in the passengers' market. Kuzminykh and Zufan (2014) conducts a panel data analysis by using the data on 65 airline companies, 14 of which were members of the three biggest airline alliances (Star Alliance, SkyTeam, OneWorld) to measure the effects of airline alliances on the performance of airline companies. Evans (2001) reviews previous studies on airline alliances and pointed out to the reasons underlying alliance formation, identified the phases of alliance formation, and distinguishes the factors that the success or failure of an alliance member airline company depends on. Agusdinata and Klein (2002) employs a system dynamic approach and identifies the situations that lead to formation of airline alliances and points out to the dynamics of the airline alliances. Amoah and Debrah (2011) studies African airlines operating within global airline alliances and examined the transition from bilateral airline alliances to multilateral airline alliances. Brueckner (2001) builds a model and examines the effects of airline alliances on traffic levels, salaries, and welfare. Goh and Yong (2006) examines whether alliances have impacts on costs and, if yes, how the cost structure of airlines are influenced.

Coopetition in the airline industry is practiced apart from the strategic airline alliances as well as within the scope of alliances. In line with, there are also studies on coopetition practices which are made by competitor airlines apart from the strategic airline alliances. Most of these studies are on agreements practicing between competitor airlines such as frequent flyer programs, code sharing, joint ventures (Lederman, 2008; Gudmundsson et al., 2002; Long et al., 2003; Whalen, 2007; Ustaömer et al., 2015).

Coopetition strategy is a business strategy employed in industries with intense competition. In this respect, this study is important for dealing with the airline industry as an intense-competition industry with a viewpoint of coopetition strategy and thus is filling the gap in the literature together with presenting different analogies to the literature on coopetition strategy about what the strategy looks like. The study is also important for it identifies the opinions of airline companies employing coopetition strategies, on coopetition strategies, which will provide guidance to other airline companies that do not currently employ coopetition strategy. 


\section{Method}

\section{Research model}

Since this research aims to identify the experiences of airline companies that employ coopetition strategies in the airline industry, qualitative research perspective has been adopted to reach detailed data, and to understand the experiences, points of view and stories, if any, of the participants (Creswell, 2007, p. 39-40; Merriam and Associates, 2002, p. 4). Within the framework of qualitative research perspective adopted for the research, phenomenology has been used as the qualitative research pattern. Phenomenology, in general, provides ability to produce new information through experiences. Phenomena are the building blocks of anthropology and the basis of all information (Moustakas, 1994, p. 26). Studies based on phenomenology aim to understand the meaning of personal experiences. Beyond that, participants are selected from among those who have experienced the phenomenon and are requested to provide data through interviews. The researcher narrows the data through several stages and develops descriptions which represent shared experiences of participants of a certain phenomenon (Creswell, 2007, p. 94). In this research, the phenomenon examined is coopetition. Since the subject of the research is the experiences and current practices of participants, who are senior managers in traditional airlines, related to coopetition and what the coopetition strategy means for the airline industry, the phenomenology pattern has been adopted for the study.

\section{Participants}

The scope of the study covers airline companies that employ coopetition strategies. These companies are generally called traditional airlines in the airline industry. The participants involved in this research are selected with the criterion sampling method from among purposeful sampling methods. The importance of purposeful sampling lies in the selection process in information-rich cases in in-depth studies. Since studies based on purposeful sampling involve information-rich cases, one may learn a lot about the issues at the center of the purpose of the research (Patton, 1990, p. 169). The criterion sampling method employed in this research, involves selection within the framework of criteria predetermined in order to identify the best suitable sampling from among the research universe (Patton, 1990, p. 176). In this research, the following criteria are taken into consideration to identify the companies;

- Being a traditional airline company which employs coopetition strategy and which is represented at senior level management in Turkey, and

- Having a senior level manager who experiences coopetitive strategies.

The following factors have been respectively decisive in selection of the criteria: the research is time- and cost-limited. Also, the reason why the participants were selected from among senior managers is that the research topic is a strategic one and senior managers are the ones who are experienced about such strategic practices and thus they can provide valid and reliable information on the topic. In line with the abovementioned criteria, the airline companies have been identified and the managers were contacted. Two communication channels were used to have appointments. The first one is the headquarters of airline companies in Turkey, and the second one is Linkedin, an online social network among professionals where senior managers can be contacted directly. Upon requests of appointment for nine traditional airlines, managers of five traditional airline companies that are members of Star Alliance and SkyTeam Alliance gave favorable replies. The literature review suggests that interviews with 5 to 20 participants would be sufficient to fulfill the purposes of a 
phenomenological research (Güler et al., 2013, p. 44). Among these traditional airline companies, two managers were contacted through Linkedin whereas the remaining three were contacted through the phones of main offices in Turkey. The interviews were conducted between April 29th and May 25th. Table 1 shows demographic data on the participants.

Table 1: Demographic data on the managers of airline companies contributing to the study

\begin{tabular}{|c|c|c|c|c|c|}
\hline Sex & Male & Female & Male & Female & Male \\
\hline Age & 31 & 50 & 37 & 43 & 45 \\
\hline $\begin{array}{l}\text { Educational } \\
\text { Level }\end{array}$ & Postgraduate & Graduate & Postgraduate & Graduate & Graduate \\
\hline $\begin{array}{l}\text { Position in the } \\
\text { Company }\end{array}$ & $\begin{array}{c}\text { Manager of the } \\
\text { Regional } \\
\text { Station }\end{array}$ & $\begin{array}{l}\text { General } \\
\text { Manager }\end{array}$ & $\begin{array}{l}\text { President of } \\
\text { International } \\
\text { Relations and } \\
\text { Agreements }\end{array}$ & $\begin{array}{l}\text { Deputy } \\
\text { General } \\
\text { Manager }\end{array}$ & $\begin{array}{c}\text { Deputy } \\
\text { General } \\
\text { Manager }\end{array}$ \\
\hline $\begin{array}{l}\text { Term of } \\
\text { Service in the } \\
\text { Position }\end{array}$ & 1 Years & 8 Months & 2 Years & 18 Years & 7 Years \\
\hline $\begin{array}{l}\text { Term of } \\
\text { Service in the } \\
\text { Company }\end{array}$ & 9 Years & 8 Months & 6 Years & 16 Years & 7 Years \\
\hline $\begin{array}{l}\text { Term of } \\
\text { Service in the } \\
\text { Airline } \\
\text { industry }\end{array}$ & 11 Years & 18 Years & 6 Years & 26 Years & 23 Years \\
\hline
\end{tabular}

\section{Data collecting tool}

In this study based on phenomenology, semi-structured interview technique has been adopted as an interview technique aimed at collection of similar data from participants on the research topic. The literature review suggests that interview is the most prominent data collection method in phenomenology research (Güler et al., 2013, p. 44). In semi-structured interviews, an interview form containing interview questions or subject headings is prepared before the interview to guide the interviewee during the interview. In this technique, since an interview form is used, the data are more systematic than unstructured interview data. This, in turn, facilitates the data regulation and analysis processes (Doğanay et al., 2012, p. 145).

The data were collected during face-to-face semi-structured interviews with the airline company managers, which were conducted at the time of appointments set by managers in audio-recordable environments where they felt comfortable to express themselves. Before the interviews, the participants signed the interview approval form, prepared in line with ethic codes, and a tape recorder was used upon the permission of the participants.

The interview form used during the semi-structured interviews was prepared upon the relevant literature review. Two experts on qualitative research methods were consulted to check whether the interview form was in line with the research pattern. Two experts on the field were consulted to check whether the research questions were in line with the research. Finally, a pilot interview was conducted to confirm the validity and reliability of the questions. The interview form was revised and finalized upon feedbacks.

\section{Data analysis and interpretation}

In qualitative data analysis, the analysis and data collection processes run simultaneously. Besides, some researchers suggest that qualitative analysis process lasts from the beginning to the end of the research (Doganay et al. 2012, p. 184). In this research, the data were analyzed with the thematic analysis technique. Thematic analysis is suggested to be the 
best suitable analysis technique in studies where interpretation is involved in the analysis. Thematic analysis provides researchers with the capability to make definite decisions on relationships between concepts and to compare them with repeated data. With thematic analysis, it is possible to connect several concepts and ideas and to compare them with the data collected in different times and places during the research (Alhojailan 2012, p. 40). In thematic analyses employed in qualitative research, first, the data collected should be written down. Then, the entire data set should be systematically coded, the themes should be identified, a theme map should be drafted, the themes should be described, and finally the data should be reported (Braun and Clarke 2006, p. 35).

In the process of data analysis of our study, the data collected with tape records were transferred to the computer and written down. The data set was read thoroughly and the message was focused on. Then, the data were read and coded line by line. The codes were examined carefully and main themes and themes were identified. This analysis was controlled by a qualitative research expert and main themes and themes were revised in direction with feedbacks. Main themes represent the research questions. Finally, a theme map was drafted and the data were reported. The research findings were explained and interpreted based on the themes described.

\section{Findings and Interpretation}

\section{The Relationship Between Main Themes and Themes}

The experiences of airline companies who employ coopetition strategies were identified by thematic analysis. The main themes and themes derived from the analysis are provided in Table 2.

Table 2: Main themes and themes

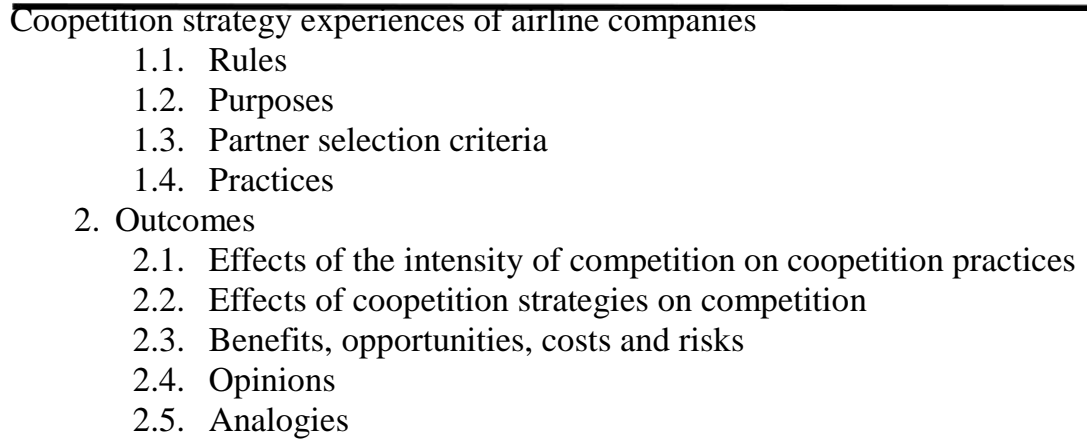

The relationship between main themes and themes emerged as a result of the thematic analysis is shown in Fig.1.

When Fig. 1. is examined, it is seen that the relationship between the main themes and the themes reflects process of coopetition practices in the airline industry. In this regard, the process first begins with the airlines' compliance with the rules and having specific objectives to implement the coopetition strategy. Airline companies can employ the strategy in two ways. It should be pointed out here that airline companies can use both ways at the same time to employ the coopetition strategy. Airline companies that prefer to involve in a strategic airline alliance apply the coopetition strategy in accordance with the strategies of the alliance with the alliance members. An important issue emerges in the coopetition practices that airline companies do apart from the strategic airline alliance. Airline companies that prefer this way to employ coopetition strategy, need to carefully select their partner airlines that will help to achieve their purposes. In this direction, two main criterion emerges. These criteria are the criteria related to the airlines' image and operational resources. At the end of the process some 
outputs emerge. These outcomes derive from effects of the intensity of competition on coopetition practices, effects of coopetition strategies on competition, benefits, opportunities, costs and risks of the strategy, the opinions of airlines and the analogies that reflect the structure of the coopetition strategy in this respect.

\section{Coopetition strategy in the airline industry}

\section{Coopetition strategy experiences of airline companies}

Participants were asked to talk about the experiences related to coopetition strategies of their companies. The findings were grouped under four themes including rules, purposes, partner selection criteria and practices.

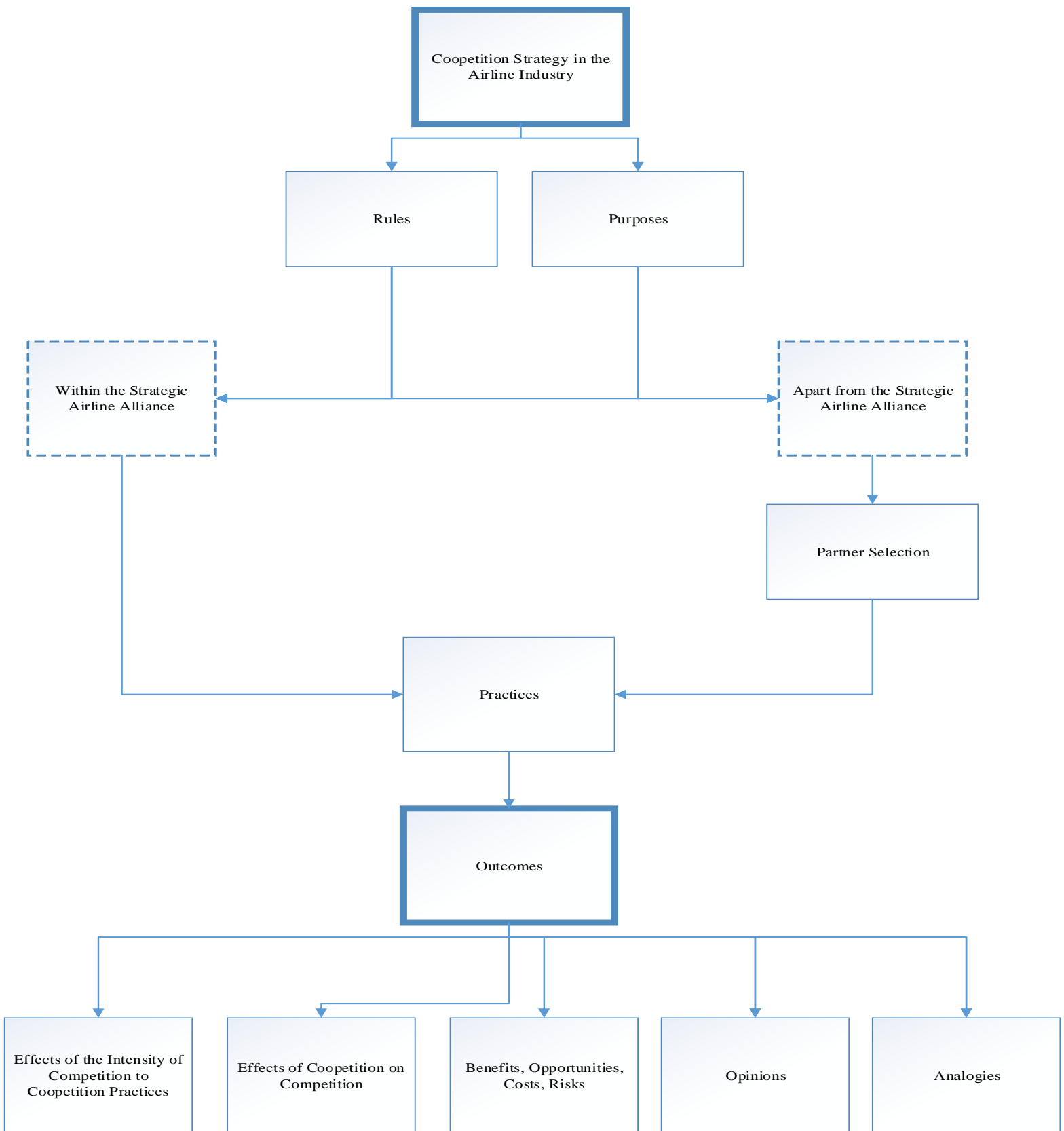

Figure 1: The Relationship between main themes and themes. Boxes with thick and thin straight lines refer to the main themes and themes respectively that emerged as a result of thematic analysis. Boxes with dashed lines were used for showing the ways of coopetition practices in the airline industry based on the findings emerged as a result of thematic analysis. 
Some of participants emphasized that there were certain requirements of coopetition. They suggested that it was not a normal situation for two competitors to cooperate, and that it was only possible in high-competition markets with special exceptional permissions from competition boards, and in line with anti-trust immunity rules. The participant 3 emphasized that competition boards should open the way for practices that would moderate the intensive competition in the industry for the sake of companies and passengers:

'... Yet, competition boards should open the way for and facilitate some practices ...'

Within the framework of coopetition, airline companies come together with competitor companies in line with certain purposes. According to the findings of the study, the purposes of coopetition in the airline industry include strategic purposes, commercial purposes, financial purposes and operational purposes (Table 3).

Table 3: The purposes of coopetition strategy

\begin{tabular}{|l|l|l|l|}
\hline Strategic Purposes & \multicolumn{1}{l}{$\begin{array}{l}\text { Commercial } \\
\text { Purposes }\end{array}$} & $\begin{array}{l}\text { Financial } \\
\text { Purposes }\end{array}$ & $\begin{array}{l}\text { Operational } \\
\text { Purposes }\end{array}$ \\
\hline $\begin{array}{l}\text { Expanding the } \\
\text { global flight } \\
\text { network }\end{array}$ & $\begin{array}{l}\text { Gaining } \\
\text { more } \\
\text { customers }\end{array}$ & $\begin{array}{l}\text { Reducing } \\
\text { costs } \\
\text { Creating } \\
\text { financial } \\
\text { resources }\end{array}$ & $\begin{array}{l}\text { Completing } \\
\text { flight activities } \\
\text { in the best } \\
\text { efficient way }\end{array}$ \\
$\begin{array}{l}\text { customers } \\
\text { from quitting } \\
\text { the alliance }\end{array}$ & $\begin{array}{l}\text { Ensuring } \\
\text { customer } \\
\text { satisfaction } \\
\text { Having }\end{array}$ & & $\begin{array}{l}\text { Having } \\
\text { openational } \\
\text { benefits }\end{array}$ \\
$\begin{array}{l}\text { information on } \\
\text { how the } \\
\text { competitors } \\
\text { run their } \\
\text { business }\end{array}$ & & & \\
\hline
\end{tabular}

The most striking finding about the purposes of coopetition is that strategic purposes include the purpose of having information on how the competitors run the business. Airline companies may aim to acquire the know-how that the competitor airline companies have derived from past experiences to use them for their own interests. The participant 2 made the following remarks to point out to the fact that some companies cooperating with competitor companies may become more powerful by using the information derived from the partner:

'There is a risk of losing know how to the competitors. It is a risk to give away the information derived from past experiences to the companies collaborated. If you do so, you create your own rival. There are companies who take this information and use it for its own benefits.'

Another significant motive behind the adoption of coopetition strategies by airline companies is to survive and to ensure sustainability. The relevant finding was expressed by the participant 1 in the following phrases:

'... It may be practiced for survival, too. If the airline company has collaboration with other companies, it may survive in that route with the help of the passengers that would derive from these companies. This is why such collaboration is practiced.'

Airline companies employ coopetition strategies due to high costs in the industry and to benefit from the advantages and facilities offered by the strategies. Here, an important point is 
the criteria for the selection of the companies to collaborate or the alliances to be a member of. In consideration of the fact that the risk of failure increases when the selection criteria are not well defined, in case of failure, the coopetition process may bring about further material and immaterial burdens while the costs are already high for airline companies. According to the findings, the partner selection criteria of the airline companies are grouped under two headings: the image of the partner company and the operational resources of the partner company (Table 4).

Table 4: Partner selection criteria

\begin{tabular}{|l|l|}
\hline \multicolumn{1}{|c|}{ Criteria About the Image } & Criteria About the Operational Resources \\
\hline - $\begin{array}{l}\text { Equity in terms of the quality of services } \\
\text { - Whether the company to be selected is a }\end{array}$ & $\begin{array}{l}\text { Complementarity in terms of the flight } \\
\text { metwork }\end{array}$ \\
- Attention to security and safety & $\begin{array}{l}\text { The slots it possesses } \\
\text { - Feeling sufficient confidence to act }\end{array}$ \\
together & - Hours of flight to the existing flight \\
- Communicational strength & \\
\hline
\end{tabular}

The image of the airline company is a significant factor which directly affects the activities and thus sustainability of the company. Any smallest problem may instantly affect the image of the airline company in the eyes of the public, and may lead to further problems for the airline company. This is best articulated by the participant 1 who said the following:

'... we work in an industry with very serious risks. An accident may finish an airline company. Take, for example, Germanwings... It had an experience of 10 years. Now the airline company does not exist ... For example, Malaysia Airlines is at the brink of bankruptcy. One of its planes got lost and the other one fell, actually shot. The airline company had nothing to do in any of them, because the plane was shot in a conflict between Russia and Ukraine. There is nothing to do, it could have happened to anybody.'

In order for the sustainability of the quality of services they offer to the customers, airline companies select airline companies with at least the same level of service quality. This ensures that the service standard is maintained. In order to maintain the standards, airline companies that are members of alliances check whether the potential partner is a member of the same alliance. Complementarity is sought in terms of operational resources. Airline companies seek to access to resources that they do not possess. Among all the criteria, airline companies pay highest attention to the safety criterion. Four among five participants emphasized safety as the most important criterion. One participant emphasized reliability as the most important criterion. In this respect, airline companies expect that the competitor airline company, with whom they are going to share a competition strategy, to pay attention to safety at least as they themselves do. The participant 1 said the following on this matter:

'Besides, we expect that the airline company has some safety certificates. We expect that they have a command of and satisfy the certificates. Certificates such as the IOSA certificate. We also make inspections, where necessary. Thus we decide on whether the company is worth collaborating or not... The most important thing is safety. Safety is the most important factor in the airline industry. An accident may affect even the most important companies having a history of 50 years or 100 years. If I have a code sharing agreement with an airline company, if I give my passengers to that company, any injury of those passengers would affect the image of my company in case of an accident. We do not want any income at the expense of any unfavorable incidents. Safety comes first.'

Coopetition practices in the airline industry are employed, including practices within the strategic airline alliances and practices apart from the strategic airline alliances. Strategic airline alliances provide the airline companies with the opportunity to grow. Strategic airline alliances may be of global or regional character. Within the strategic airline alliances, airline 
companies may sign code sharing agreements, let passengers use the central airport lounges of the member airline companies, and work with common maintenance companies, common ground services companies, and common catering companies. Thus, high costs may be reduced to some extent through common facilities. The member airline companies of alliances come together for common interests while they continue to compete in other areas. The significant point that should be noted in the employment of this strategy is that airlines should be aware that they would not be able to carry out their own sustainable efforts. Participant 5 stated these practices as follows:

'There are two ways for practicing coopetition in the world. One of these is membership systems such as Star Alliance, SkyTeam and Oneworld. The other is code share agreements except for this membership.'

One of the most significant contributions of strategic airline alliances to its member airline companies is the standardization of the services purchased and offered to the customers, and the possibility to maintain the trademark value. The findings suggest that membership to strategic airline alliances is indispensable especially for big airline companies targeting the top position in the global airline industry. This is because airline companies that are members of strategic airline alliances gain a significant competitive advantage over their competitors that are not members of such alliances. Besides, in some routes, alliances provide airline companies with certain resources to make advertisement and promotion of the alliances, and thus make an effort to increase the number of potential passengers.

In the airline industry, coopetition strategies may also be employed apart from the strategic airline alliances. These practices include code sharing, joint ventures, and so on. This finding was expressed by the participant 4 in the following remark:

\begin{abstract}
Apart from the alliance, we have code sharing practices. I will explain what it is. It is the number of seats that we, as airline companies who do not fly or have few flights in a specific destination, offer to each other in order to increase the number of passengers in mutual traffic. They depend on the agreements. Let me put it this way. If you fly with a B777-200, which means if you have a capacity of 261 passengers, you reserve 20-30 seats for the other airline company under the terms of the agreement. If the other airline company sells these seats, they pay you from the money in the reserve. If they cannot sell, they have a specific time limit. If the seats are not sold within the time limit, then the seats are cancelled; this is what we call code sharing agreement. Although you are competitors, this is practiced by a lot of airline companies.
\end{abstract}

Due to certain regulations in the industry, airline companies cannot fly in any route they desire. And they cope with these restrictions through the agreements they make with the airline companies that fly in those routes. Besides, they can also use this strategy to feed their existing routes. Airline companies aim to increase the efficiency of the main routes by connecting other routes to the existing routes that they would like to feed.

Airline companies have the responsibility to deliver airline services to people; but they are also commercial enterprises that aim to make profits. There are also commercial motives behind the gathering of these companies. These motives are to gain more customers and to ensure customer satisfaction. The purpose is to increase incomes by gaining more customers and to fix their existing passenger potentials, which means potential income, by ensuring customer satisfaction. This allows airline companies, which are vulnerable to risks, crises and uncertainties, to eliminate the economic uncertainties at least to some extent and to make better predictions for the future, thus not avoid making investments.

\title{
Outcomes
}

While coopetition strategies have effects on airline companies and the industry, it was seen that the intensity of competition in the market also affects the forms of coopetition strategies of airline companies. Participants confirm the significance of the strategy for the 
industry. All participants believe that coopetition strategies are indispensable for the airline industry. The participant 4 made the following remarks on the subject:

'Coopetition is a strategy that originates from the needs. This is because everybody knows that competing on your own, you cannot achieve anything in this market. That is to say, everybody bankrupts. You need to achieve low costs, and there are similar airline companies... You need to build a partnership. Actually, the economic conditions force us to do this.'

The participants consider the coopetition strategy as a must for the airline industry. If we focus on the conclusions to be derived from that, although the coopetition strategy brings about certain costs and risks for the industry, the benefits and opportunities that it offers overweigh. Based on the findings, Table 5 shows the benefits, opportunities, costs and risks (BOCR) of the coopetition strategy for the airline companies.

Table 5: Benefits, opportunities, costs and risks (BOCR) of the coopetition strategy

\begin{tabular}{|l|l|}
\hline Benefits & - Reduced costs \\
- Increased number of points of arrival \\
- Some business processes are shared between partners \\
- Benefiting from the resources of the competitors \\
- Standardization of the services offered to the customers \\
- Survival of small companies \\
- Competitive advantages \\
- Increased recognition \\
- Promotion of innovation \\
- Sustainability \\
\hline Opportunities & $\begin{array}{l}\text { - Opportunity to grow at global level and expand the flight network } \\
\text { - Opportunity to share risks }\end{array}$ \\
- Opportunity of eased operation \\
- Opportunity of service integrity \\
- Increased options offered to customers \\
- Opportunity to offer cheaper tickets to passengers \\
- Opportunity to address to increased number of passengers \\
\hline Costs & $\begin{array}{l}\text { - Infrastructure costs } \\
\text { - Additional costs of insurance and safety } \\
\text { - Rosts of extra staff } \\
\text { - Risk of self-seeking - unilateral gains } \\
\text { - Rlliance membership fees }\end{array}$ \\
\hline - Risks of empowering the competitor \\
- Risk of losing knowhow
\end{tabular}

To achieve corporate strategy, managers should do analysis of BOCR criteria. This is a kind of multi criteria decision problem in strategic management. Using benefits, 
opportunities, costs and risks of the coopetition strategy, airline managers may effective decision making via sound analysis in timely manner. Another important thing is in this point, airline managers tailoring this table according to their both aim, objectives, sources and managerial risk management attitude. For this reason, managers may seize chance of the achievement their corporate strategy via analyzing of Table 5 according to airline-company specified way. To this aim, in view of our research results, when Table 5 is examined, it is seen that the most important benefits of the coopetition strategy for airline companies are reduced costs, survival of small companies and sustainability in line with data obtained. Among the opportunities, the opportunity to share risks is particularly important when the airline company is about to enter a new market or make a new investment. Besides, it is also important that the strategy provides the companies in search of growth with the opportunity to expand their global flight network. An analysis of costs shows that the strategy creates rather material costs for airline companies. The most significant risks of the strategy are the risk of empowering the partner and the risk of losing the existing markets. Some of views expressed by participants in terms of benefits, opportunities, costs and risks of the strategy are as follows:

Participant 4 stated that low cost is the greatest advantage of a coopetition strategy saying "...You use a common lounge, a common handling system. As a matter of fact, this is also a cost saving thing. The greatest benefit to this strategy is the low cost...". The other participants cite opportunities, costs and risks as the other benefits of the strategy:

P3: “... the number of destinations we fly to also increases. This is a great advantage to the customer. In some regions, the partners manage the processes. We can also benefit from each other's resources. For instance, while airline A benefits from the convenience created in X city, airline B is on the forefront in Europe and C completes the process in America..."

Participant 5 sees opportunities to access previously out of reach customers, as well as flying the passengers to points you could not fly to as one of the opportunities created by the coopetition strategy with the following words "One of the greatest opportunities is that is provides the chance to reach passengers that you otherwise could not access. It gives your passengers a chance to fly to places you cannot fly to..."

Participant 2 contends that the coopetition strategy provides a risk sharing platform: "...At the same time, it provides an opportunity to share calculable risks. Entering a new market is obviously always a risky affair in terms of cost..." P1 corroborates by saying that the application of this strategy, especially in more competitive markets, provides an opportunity to reduce the risks stating "For instance, the US is quite a competitive market. Getting into alliance with a strong airline their will substantially reduce your risk..."

P4: “... looking at it from the cost aspect, being affiliated to an institution has its costs as well as costs incurred in the processes of understanding and seeking to comply with the standards. And since you are faced with the obligation of becoming more institutionalized, you get to incur more costs to achieve this. You have the cost of infrastructure..."

P1: “...there may also be the risk of losing one's market. You support a less powerful airline, that airline gets a toe-hold of the market. In the future, the airline you supported may end the alliance and become a formidable competitor. Maybe you may end up being the stepping stone of a competitor you could have put out of action by not cooperating ..."

When the findings are analyzed regarding whether the intensity of competition in the existing markets have any effect on the coopetition strategy, the findings show that the coopetition strategy changes depending on the intensity of the market, the intensity of the season, the customer demand, and the safety of the market. The most striking finding was expressed by the participant 1 :

'For example, the USA is a very competitive market. Cooperation with a strong airline company there would reduce your risks... For example, you can start offline code sharing, check if there is customer 
demand, and if the route works. Then you can turn that route into online. Thus you start to fly in that route. You want to have cooperation where you need to have cooperation. While you decide what, where, why should be done, the status of the market, your capability to reach there, the safety level of that market... all these matter. Sometimes you cannot have a direct flight to that market for safety reasons or other reasons. This is also a criterion.'

The findings about the effects of coopetition strategies on competition in the industry show that coopetition strategies keep the competition in the airline industry in balance and have positive effects on competition. Yet, this may vary depending on the routes.

Regarding the coopetition strategy, the participants were interpreted the market-pie example of Brandenburger and Nalebuff (1998) in the case of the airline industry. Based on the example, the participants revealed that employing the coopetition strategy, airline companies protected and developed the industry, made it sustainable, and since the pie grew, they had bigger slices too, and the airline companies grew together.

Based on their coopetition experiences, the participants were asked to liken the coopetition strategy to something they would like in order to concretize their perception of the strategy. Different findings were obtained. The analogy of each participant is given in Table 6.

Table 6: Analogies of the participants regarding the coopetition strategy

\begin{tabular}{ll}
\hline Participant & Analogy \\
\hline P1 & Two close friends drinking tea \\
\hline P2 & The strategy of keeping the enemy close \\
\hline P4 & A puzzle that complements one another \\
\hline P5 & $\begin{array}{l}\text { A scale which always aims to keep its own } \\
\text { side up }\end{array}$ \\
& $\begin{array}{l}\text { Being with the competitor in a luminous } \\
\text { room }\end{array}$
\end{tabular}

\section{follows:}

Participants expressed their thoughts on their analogies in Table 6 respectively as

'...To illustrate, we can say close friendship. Collaborations in the airline industry are like that two close friends are drinking tea together. "

'If I'm going to make an analogy, I can call this strategy is a strategy to keep the enemy close. If I hold close to my enemy, I will have a better chance of evaluating what is happening and what is going on. If I hold it away, it might get out of sight. "Then they can gain a superiority over me in competition...'

'If I'm going to make an analogy for this strategy, I can call this strategy as a puzzle that complements one another owing to the fact that I will want to make these agreements with airlines which complete my flight network for the sake of customers' choices increase.'

'It's actually very interesting. You are all friends. You sit outside and talk, but there are also areas where you try to protect yourself and your company. You do not share everything. It's a scales that always want to leave your side up. Because people are not too honest.'

'This strategy gives us the opportunity to reach the passengers that we cannot reach in a positive way. Negatively, you present your customers to someone else...If we were to make an analogy; we can say to be in a brighter light room with the competitor to make sure everything is transparent.' 


\section{Conclusions}

This phenomenological study sets out identify the experiences of airline companies employing coopetition strategies with reference to the senior managers. The results show that coopetition strategy has significant conclusions for the airline industry.

The coopetition strategy is a quite common strategy in the airline industry, especially among big carriers. Airline companies practice coopetition with competitor airline companies in certain business areas in various forms such as code sharing, is the most used form, participating in alliances or not and joint ventures in line with mutual interests while they maintain competition in other areas. The significance of such practices between competitor companies increases each day even more for the airline companies who strive to survive or wish to grow. Depending on the power of the airline company, the strategy may mean either a survival strategy (Bonel and Rocco, 2007) or a growth strategy. For instance, the study shows that airline companies can grow on their own up to a certain level and they need to adopt coopetition strategies to grow more. This is because collaboration provides competitive advantages that an airline company cannot achieve on its own. Thus, the airline companies involved in coopetitive relationships have increased competitive advantages and been sustainable compared to their competitors struggling alone. Besides, coopetition strategies help to the industry for its protection, growth of the pie, and maintaining the sustainability.

Coopetition strategy can be employed in two ways in the airline industry. The first way is to involve a strategic airline alliance. The second way is also the agreements among competing airline companies apart from alliances. The most critical conclusion of the study is that the coopetition strategy is very important for the airline industry. In this respect, the coopetition strategy is an indispensable strategy for the sustainability of airline companies, whether they are traditional airlines or low cost carriers (LCCs). Morrish and Hamilton (2002) and Kuzminykh and Zufan (2014) reveal why this strategy are indispensable and their benefits to airlines. The airline industry is a high cost industry to operate. In this respect, one of the prominent benefits that the strategy offers to airline companies is reduced costs. Airline companies are increasing their common facilities in order to reduce costs and sharing costreducing experiences with each other.

Another important conclusion is that safety and security are the most significant criteria for airline companies for the selection of partner for the purpose of coopetition. Even any smallest accident of partner company may harm the image of the other's. Accordingly, Gerede (2015) points out that international and domestic regulatory authorities and airlines makes endeavor about carrying out aviation activities safely and securely. A different conclusion also states that the form of the coopetition strategy employed by airlines is affected by the intensity of competition in the market, the customer demand, and the safety of the market.

In summary, coopetition strategy is a useful strategy for airline industry although it has some risks. There are some responsibilities for both international authorities and airline companies and other stakeholders in removing and preventing these risks. In this scope, the authors have two recommendations as a result of this qualitative study. First, competition boards are required to lead up practices which will benefit airline companies, thus passengers in line with own context of each practice. Second, airline companies should take measurements relating such negative situations as opportunism, trust problem and so on, during designing process of coopetition agreements in line with their own practice. The important point is that qualitative studies are context-specific studies in which they are conducted and findings are shaped by authors' interpretations. Therefore, the results obtained from these studies are not generalizable and may be considered together with similar results obtained from similar studies. 


\section{Acknowledgement}

This paper is based on a Master's thesis titled "Coopetition Strategy in the Airline Industry: A Research on Traditional Airline Companies" completed at Anadolu University Graduate School of Social Sciences under the supervision of Assoc. Prof. Dr. Ayse Kucuk Yilmaz in 2016. Also this study was supported by Anadolu University Scientific Research Projects Commission under Grant [1602E060].

\section{References}

Agusdinata, B. \& Klein, W. (2002). The dynamics of airline alliances. Journal of Air Transport Management 8: 201-211.

Akdoğan, A. A. \& Cingoz, A. (2012). An Empirical Study on Determining the Attitudes of Small and Medium Sized Businesses (SMEs) Related to Coopetition. Procedia - Social and Behavioral Sciences 58: 252-258.

Akdoğan, A. A., Doğan, N. Ö. \& Cingöz, A. (2015). Coopetition as a business strategy: Determining the effective partner selection criteria using fuzzy ahp. International Review of Management and Business Research 4(1): 137-151.

Alhojailan, M. I. (2012). Thematic analysis: A critical review of its process and evaluation. West East Journal of Social Sciences 1(1): 39-47.

Amoah, J. A. \& Debrah, Y. A. (2011). The Evolution of Alliances in the Global Airline Industry: A Review of the African Experience. Thunderbird International Business Review 53(1): 37-49.

Bengtsson, M. \& Kock, S. (2000). "Coopetition" in business networks - to cooperate and compete simultaneously. Industrial Marketing Management 29: 411-426.

Bonel, E. \& Rocco, E. (2007). Coopeting to survive; surviving coopetition. International Studies of Management and Organization 37(2): 70-96.

Brandenburger, A. M. \& Nalebuff, B. J. (1998). Ortaklaşa rekabet. (Trans. L. Cinemre). Istanbul: Scala Yayınc1lik.

Braun, V. \& Clarke, V. (2006). Using thematic analysis in psychology. Qualitative Research in Psychology 3(2).

Brueckner, J. K. (2001). The economics of international codesharing: An analysis of airline alliances. International Journal of Industrial Organization 19: 1475-1498.

Chang, W. L. \& Chiu, C. L. (2016). Coopetition under alliance? applying awarenessmotivation-capability competitive dynamics perspective. Journal of Business Economics and Management 17(5): 701-716.

Chen, X. \& Hao, G. (2013). Co-opetition alliance models of parallel flights for determining optimal overbooking policies. Mathematical and Computer Modelling 57: 1101-1111

Chiambaretto, P. \& Fernandez, A. S. (2016). The evolution of coopetitive and collaborative alliances in an alliance portfolio: The Air France case. Industrial Marketing Management 57: 75-85.

Creswell, J. W. (2007). Qualitative inquiry and research design: Choosing among five approaches. Thousand Oaks: Sage Publications.

Czakon, W., Kuś, K. M. \& Rogalski, M. (2014). Coopetition research landscape-A systematic literature review 1997-2010. Journal of Economics and Management 17: 122-150.

Demirel, Y., Keskin, N., Ülgen, H., Yozgat, U. \& Bas, T. (2011). Kredi kartları pazarında ortaklaşa rekabet stratejisi: Advantage kredi kartı üzerine bir araştırma. Yönetim 22(68): 73-90.

Demirel, Y., Arzova, B., Ardıc, K. \& Bas, T. (2013). Organizational learning on coopetition strategy: An exploratory research on a Turkish private banks credit card application. Procedia - Social and Behavioral Sciences 99: 902-910. 
Dennis, N. (2005). Industry consolidation and future airline network structures. Journal of Air Transport Management 11: 175-183.

Doğanay, A., Ataizi, M., Şimsek, A., Balaban, J. \& Akbulut, Y. (2012). Sosyal bilimlerde arastirma yontemleri. Eskisehir: Anadolu University.

Evans, N. (2001). Collaborative strategy: an analysis of the changing world of international airline alliances. Tourism Management 22: 229-243.

Ganguli, S. (2007). Coopetition models in the context of modern business. The ICFAI Journal of Marketing Management 6(4): 6-16.

Gerede, E. (2015). A study of challenges to the success of the safety management system in aircraft maintenance organizations in Turkey. Safety Science 73: 106-116.

Gnyawali, D. R. \& Park, B. J. (2009). Co-opetition and technological İnnovation in small and medium-sized enterprises: A multilevel conceptual model. Journal of Small Business Management 47(3): 308-330.

Goh, M. \& Yong, J. (2006). Impacts of code-share alliances on airline cost structure: a truncated third-order translog estimation. International Journal of Industrial Organization 24: 835-866.

Gudmundsson, S. V., De Boer, E. R., \& Lechner, C. (2002). Integrating frequent flyer programs in multilateral airline alliances. Journal of Air Transport Management 8: 409-417.

Güler, A., Halicioglu, M. B. \& Taşgin, S. (2013). Sosyal bilimlerde nitel araştırma yöntemleri (First Edition). Ankara: Seçkin Yayıncılık.

Huang, H. C. \& Chu, W. (2015). Antecedents and consequences of co-opetition strategies in small and medium-sized accounting agencies. Journal of Management and Organization 21(6): 812-834.

Kim S., Kim N., Pae J. \& Yip L. (2013). Cooperate "and" compete: coopetition strategy in retailer-supplier relationships. Journal of Business \& Industrial Marketing 28(4): 263 275.

Klimas, P. (2014). Multifaceted nature of coopetition inside an aviation supply chain - The case of the aviation valley. Journal of Economics and Management 17: 96-119.

Kozyra, B. (2012). Strategic alliance as a particular form of coopetition. Global Management Journal 1(2): 27-38.

Kuzminykh, N. \& Zufan, P. (2014). Airline alliances and their influence on firm performance. Procedia Economics and Finance 12: 329-333.

Lacoste, S. M. (2014). Coopetition and framework contracts in industrial customer-supplier relationships. Qualitative Market Research 17(1): 43-57.

Lederman, M. (2008). Are frequent-flyer programs a cause of the "hub premium"?. Journal Compilation 17(1): 35-66.

Long, M. M., Clark, S. D., Schiffman, L. G. \& McMellon, C. (2003). In the air again: Frequent flyer relationship programmes and business travellers' quality of life. International Journal of Tourism Research 5: 421-432.

Luo, Y. (2007). A coopetition perspective of global competition. Journal of World Business 42: $129-144$.

Meneses, J. A. (2015). Partner selection in co-opetition: A three step model. Journal of Research in Marketing and Entrepreneurship 17(1): 23-35.

Merriam, S. B. \& Associates. (2002). Qualitative research in practice. San Francisco: Wiley Company.

Morrish, S. C. \& Hamilton, R. T. (2002). Airline alliances-who benefits?. Journal of Air Transport Management 8: 401-407.

Morris, M. H., Kocak, A. \& Ozer, A. (2007). Coopetition as a small business strategy: implications for performance. Journal of Small Business Strategy 18(1): 35-55. 
Moustakas, C. (1994). Phenomenological research methods. Thousand Oaks, California: Sage Publications.

Nasr, E. S., Kilgour, M. D. \& Noori, H. (2015). Strategizing niceness in co-opetition: The case of knowledge exchange in supply chain innovation project. European Journal of Operational Research 244(3): 845-854.

Patton, M. (1990). Qualitative evaluation and research methods. CA: Sage.

Quint, B. (1997). Coopetition: sleeping with the enemy. Information Today, 14(1): 7.

Rhoades, D. L. and Lush, H. (1997). A typology of strategic alliances in the airline industry: Propositions for stability and duration. Journal of Air Transport Management 3(3): 109I 14.

Solesvik, M. Z. \& Westhead, P. (2010). Partner selection for strategic alliances: Case study insights from the maritime industry. Industrial Management \& Data Systems 110(6): 841-860.

Sroka, W. (2013). Coopetition in the steel industry - Analysis of coopetition relations in the value net. Metalurgija 52(1): 127-130.

Stein, H. D. \& Ginevicius, R. (2010). New co-opetition approach for supply chain applications and the implementation a new allocation rule. 6th International Scientific Conference, Vilnius: Vilnius Gediminas Technical University. 1092-1099

Thomason, S. J., Simendinger, E. \& Kiernan, D. (2013). Several determinants of successful coopetition in small business. Journal of Small Business and Entrepreneurship 26(1): $15-28$.

Tsai, W. (2002). Social structure of "coopetition" within a multiunit organization: Coordination, competition, and intraorganizational knowledge sharing. Organization Science 13(2): 179-190.

Ustaömer, T. C., Durmaz, V. \& Lei, Z. (2015). The effect of joint ventures on airline competition: The case of American airlines, British airways and Iberia joint business. Procedia - Social and Behavioral Sciences 210: 430-439.

Yami, S., Castaldo, S., Dagnino, G. B., Roy, F. L. \& Czakon, W. (2010). Introduction coopetition strategies: Towards a new form of inter-organizational dynamics?. Coopetition: Winning Strategies for the 21st Century (s. 1-19). Cheltenham: Edward Elgar Publishing Limited.

Zhang, A., Hui, Y. V. \& Leung, L. (2004). Air cargo alliances and competition in passenger markets. Transportation Research Part E 40: 83-100.

Zhang, J. \& Frazier, G. V. (2011). Strategic alliance via co-opetition: Supply chain partnership with a competitor. Decision Support Systems 51: 853-863.

Whalen, W. T. (2007). A panel data analysis of code-sharing, antitrust immunity, and open skies

treaties in international aviation markets. Rev Ind Organ 30: 39-61.

Wilhelm, M. M. (2011). Managing coopetition through horizontal supply chain relations: Linking dyadic and network levels of analysis, Journal of Operations Management 29: 663-676. 